\title{
Introduction: Special issue celebrating the life and work of Larry E. Smith
}

\author{
Kingsley Bolton ${ }^{1}$ I Daniel R. Davis ${ }^{2}$ \\ ${ }^{1}$ School of Humanities, Nanyang Technological University, Singapore \\ 2 Department of Language, Culture, and Communication, University of Michigan-Dearborn, \\ USA
}

\section{Abstract}

This brief introduction provides a short biography of Professor Larry Eugene Smith, who passed away in December 2014. The introduction also discusses the contents of this special issue, which pays tribute to the life and work of Professor Smith. All of the sixteen substantive articles have been contributed by Larry's friends and colleagues from the US as well as from many other societies worldwide. Larry's personal and professional reach was truly international in scope, as this collection of articles bears direct witness.

\section{I LARRY SMITH'S LIFE AND TIMES}

Larry Smith was born in Osceola, Arkansas on June 19, 1941, and studied for his first degree at Arkansas State University. In the early 1960s, he joined the Peace Corps, and went to Thailand to teach English as a foreign language. ${ }^{1}$ After four years in Thailand, he went to the University of Hawai'i for further studies, and in 1970 he was offered a post at the University's East-West Center to develop programs for teachers of English as a foreign language from Asian societies. He then became a research associate with the Culture Learning Institute and the Institute for Culture and Communication, before eventually becoming the Director and Dean of the Education Program at the East-West Center. After retiring from the Center in 1999, Smith joined a consultancy, Christopher, Smith \& Associates LLC, that provided courses in leadership education (East-West Center, 2018).

Larry Smith met Braj B. Kachru in the late 1970s, and in 1978, two conferences were held one at the University of Hawai'i and the other at the University of Illinois at UrbanaChampaign - which began the partnership between Professors Kachru and Smith that essentially founded the world Englishes (WE) project, and that, in time would lead to the establishment of the World Englishes journal in 1985, and the creation of the International Association for World Englishes (IAWE) in May 1992. Throughout his professional and personal life, Larry Smith worked tirelessly, through the journal, related publications and the IAWE conferences to promote English studies worldwide in a spirit of inclusiveness, tolerance and respect for cultural and linguistic diversity (Yano, 2015). His engagement in the world Englishes project was partly motivated by his earlier experiences in the Peace Corps, as he later explained in an interview with Sines (2006). For Smith, his experiences overseas had made him realize that English teaching was sometimes seen as imperialistic:

This is the author manuscript accepted for publication and has undergone full peer review but has not been through the copyediting, typesetting, pagination and proofreading process, which may lead to differences between this version and the Version of Record. Please cite this article as doi:

10.1111/weng. 12325 .

This article is protected by copyright. All rights reserved. 
I realized that in my naiveté as a Peace Corps volunteer, I had actually been a part of a kind of neocolonialism, that with all good intentions, I was teaching people to use American English and I was saying, here, as you are speaking English, here's what you should sound like or here's the way you should behave. [...] And here's the way you should raise your children, and here's the way you should build your buildings. Well, that's pretty colonial. [...] I hadn't realized that [...] the Peace Corps very easily could be identified as an organization for the U.S. government to spread its propagandistic ideas about what's good about the country and not talk about racism or not talk about inequality of the people who are living, who are all American citizens. So then that helped me to look at perhaps Gandhi and Nehru, using English to unite a region of the world, to fight against a group of people who were also English speakers and talk with them about liberty and democracy and what it means to have equality. (Sines, 2006, pp. 6-7)

Later in the same interview, Smith goes on to explain that he saw his mission in the EastWest Center as that of promoting understanding, or more specifically, promoting 'better understanding among the people of Asia, the Pacific and the United States', and that vision extended to English teaching as 'these people who were studying English [...] they have the same linguistic code, so that would perhaps help them find each other intelligible or comprehensible' (Sines, 2006, p. 13). Larry's vision of promoting international understanding informed so many aspects of his work, not only at the East-West Center and in his work for the World Englishes journal, but also in his numerous publications on intelligibility, intercultural communication, and multicultural diversity. The essays in this special issue thus pay tribute not only to the scholarly accomplishments of Larry Smith, but also to his vision of international cooperation and understanding.

\section{2 | THE APPRECIATION OF LARRY SMITH'S MANY CONTRIBUTIONS}

The first essay in this issue is by Fred E. Anderson from Kansai University, Japan. In this article, Anderson explores the issue of intercultural communication in the context of Japanese higher education, research which is directly influenced by Larry Smith's work on cross-cultural communication and discourse analysis. For Anderson, one major conclusion emerging from this study is that intercultural awareness is a skill needed not only by users of English from the Expanding and Outer Circles, but equally, if not more, by language users from Inner Circle societies as well. The second contribution from Yasemin Bayyurt of Boğaziçi University, Turkey, focuses on another major strand of Smith's research, that of intelligibility. For Bayyurt, the study of intelligibility has practical implications for pedagogy, as in the Turkish context (and no doubt many other places worldwide), learners need to become familiar with a range of Inner Circle, Outer Circle and Expanding Circle varieties of English. The third paper from Margie Berns of Purdue University, also tackles the issue of intelligibility and pedagogy, with Berns noting that, partly as a result of Smith's research, today, 'language teaching professionals have a nuanced framework to refer to in setting classroom objectives and goals, in developing instructional activities and materials, and in designing assessment measures'.

Smith's research on intelligibility also informs the fourth article from Tej K. Bhatia of Syracuse University. In this article, Bhatia undertakes a forensic analysis of the fractured communications of a Vietnamese immigrant who shot and killed 13 people at an immigration centre in New York State in 2009. In part, Bhatia's analysis suggests that one possible reason for this tragic occurrence was as a result of perceived social discrimination 
against the perpetrator, who felt victimized by the police, his ESL teacher, and fellow students.

The fifth paper from Kingsley Bolton and Daniel Davis presents an overview of Smith's work, across a range of intellectual engagement, including Smith's advocacy of English as an International Auxiliary Language (EIAL), intercultural communication, intelligibility studies, as well as his invaluable work as a founding editor of the journal World Englishes. The sixth article by Eyamba $G$. Bokamba from the University of Illinois at Urbana-Champaign highlights the complexities of multilingual societies, and not only provides an overview of the complexity of multilingual language acquisition in Africa, but also reports on original empirical research that document 'the multiple pathways through which Africans develop functional fluency in several languages throughout their lives'. Following this, Elizabeth Mary Christopher from Australia discusses Larry Smith's work on cross-cultural communication, and pays tribute to Larry's ability to connect with peoples from so many different countries and cultures worldwide, as well as 'Larry's uncanny ability to recognize, across cultural and social barriers, the true nature of the people with whom he interacted'. The eighth article by Wimal Dissanayake of the University of Hawai'i focuses on Larry Smith's interest in communication studies, noting Smith's belief in the use of language to convey communicative meaning, as well as the phenomenon of miscommunication in intercultural and international contact.

The ninth article from Ravinder Gargesh of the University of Delhi also discusses Larry Smith's research on intelligibility, noting that an important achievement of Smith's work was that it 'dispelled the native speaker-centric attitude towards the non-native varieties of English [... which] broadens acceptance of varieties in their own right'. The tenth article from Suzanne K. Hilgendorf of Simon Fraser University situates the discussion of Smith's work within the wider history of the WE enterprise, the paradigm of English as an International Auxiliary Language (EIAL), before proceeding to a discussion of 'center and periphery' in world Englishes. The eleventh article from Nobuyuki Hino of Osaka University provides an illuminating account of Smith's pioneering work on English as an International Language, which achieved an important impact in the Japanese context. The following paper from Cecil Nelson of Indiana State University again focused on Larry Smith's research on intelligibility, noting that Smith's contribution in this area helped inform investigations of world Englishes in multiple contexts from diverse and insightful perspectives, passing on to us 'a set of apparatus that will always be found eminently useful in our professional and personal lives'. The thirteenth article from Rajeshwari V. Pandharipande of the University of Illinois at Urbana-Champaign discusses the use of English in Hindu practices in the US, with reference to the way in which Hindus in the US can enter a virtual temple online in order to conduct religious worship, where English is the language used by the Hindu priest. Such practices raise important issues in relation to cross-cultural communication and communities of practice.

The fourteenth article is by Zoya G. Proshina from M. Lomonosov Moscow State University. In this article, Proshina discusses Smith's work on intelligibility with reference to WE theory, noting that this theory is not only important in the context of English as an international language, but is also directly applicable to translation studies, and Proshina finally concludes that 'Intercultural Communications Studies [...] must become part and parcel of translation training'. The next article by S. N. Sridhar and Kamal K. Sridhar of Stony Brook University considers Smith's work on intelligibility with particular reference to Outer 
Circle multilingual societies, before presenting an insightful analysis of language mixing in the Indian context, concluding that 'the investigation of the use of multilingual repertoires in the dynamics of intercultural communication' have the strong potential to expand our theories of language in context and language use. The sixteenth paper from Jonathan Webster of the City University of Hong Kong offers a rather different tribute to Larry Smith's life and work, focusing less on Larry's formal academic outputs, and much more specifically on a poem written in honor of himself and Braj B. Kachru, a poem entitled 'Language as power', written by the Singapore poet Edwin Thumboo. In this final essay, Jonathan Webster highlights the spiritual aspect of Smith's work, and Larry's hope (expressed subtly in many aspects of his work) that 'one day beauty, harmony, justice, comfort, joy, and community will come to fruition'.

It is noteworthy that the sixteen contributions discussed above are from colleagues of many different nationalities, based in eight different countries, that is, Australia, Hong Kong, India, Japan, Russia, Singapore, Turkey and the US (including one contribution from Smith's beloved Hawai'i). The internationalism of these contributions is a reflection of the global scope of Smith's scholarly interests, and a final paper in the collection takes the form of a bibliography of Larry Smith's work, which includes articles on English as an international language, intercultural communication and intelligibility.

\section{3 | CONCLUSION}

Larry Smith's contribution to world Englishes was foundational and invaluable. Together with Braj B. Kachru and Yamuna Kachru, he was of crucial importance in founding world Englishes studies as we know them today. It is now sadly the case that the founding fathers and founding mother of world Englishes have passed on, but their contribution and their heritage remains with us. It is up to us, all those remaining in the WE movement, to maintain the high standards of scholarship and ethical principles bequeathed to us by the founders of the WE paradigm, the founding editors of this very journal. The sixteen substantive articles in this special issue pay tribute to an educational leader who devoted his life to multicultural and multilingual education. The legacy left to us by the founders of world Englishes has given us not only rich intellectual resources for diverse teaching initiatives, continued research, and new scholarly endeavors, but also important guidelines, both humanist and spiritual, for ethical behavior in many different areas of our academic lives.

NOTE

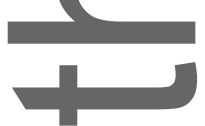

${ }^{1}$ The majority of articles in this special issue were first presented at a symposium on 'Celebrating the life and work of Larry E. Smith' held at The East-West Center, Honolulu, Hawaii, July 8, 2016.

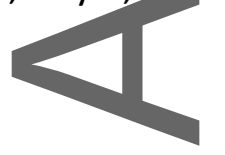




\section{REFERENCES}

East-West_Center. (2018). East-West Center oral history project: Larry Smith. Retrieved from https://www.eastwestcenter.org/research/research-information-services/oral-historyproject/larry-smith

Sines, A. (2006). Interview with Larry Smith. East-West Center Oral History Project Collection. Honolulu, Hawaii: East-West Center.

Yano, Y. (2015). Larry E. Smith, co-founder of World Englishes, dies at 73. Asian Englishes, $17(1), 88-90$.

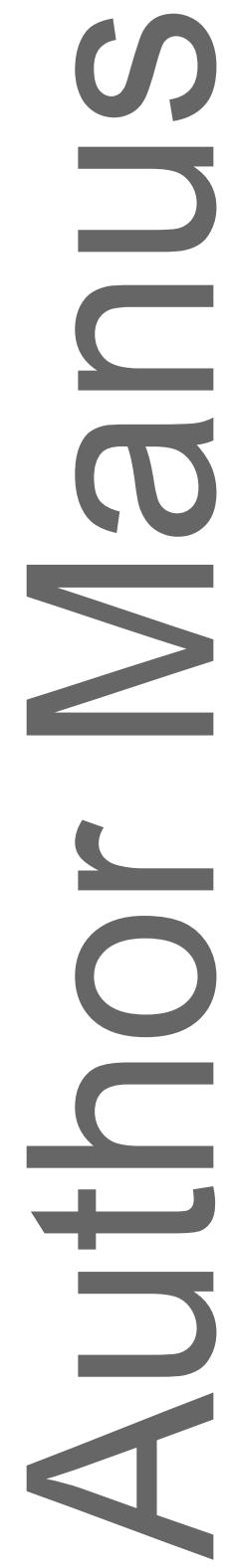

